\title{
Generational Differences Impact On Leadership Style And Organizational Success
}

Mecca M. Salahuddin, University of the Incarnate Word, USA

\begin{abstract}
Many factors can affect organizational success. One factor that is important to organizational success is effective leadership. Research has shown there are differences in leadership style among generations. A cohort- group whose length approximates the span of life and boundaries and fixed by peer personality defines a generation. The purpose of this paper is to review the current leadership styles and generational differences literature. The paper examines whether there is a relationship between leadership style and generational cohort and its potential impact on organizational success. Structured interviews were conducted with individuals representing each generation. Five open-ended questions were asked to participants to determine the generation they identified. In addition, participants used a 1-10 ranking scale to identify preferred characteristics in admired leaders. The interviews demonstrated there are difference and similarities among the generations. Veterans and Generation Xers view honesty as important core values. Both express the need for communication in bridging the communication gap. Differences related to Baby Boomer belief in self-commitment and Veterans recognizing the importance with surrounding yourself with others. The author recommends researchers continue to examine, using an empirical method, generational differences and leadership styles to understand its affect on organizational success.
\end{abstract}

Keywords: generations, organizational success, leadership styles, age differences, work relationships, organizational leadership

\section{INTRODUCTION}

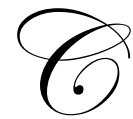

an Generation Xers effectively lead Baby Boomers? Organizations are focusing their attention on effective leadership and employee satisfaction as potential influences on organizational success. In the past, many organizational challenges would be resolved by focusing on issues of gender and ethnic differences. However, organizations have failed to address issues related to generational differences that may have a significant impact on the leadership and success of the organization. In today's workplace, organizations are experiencing issues of effective communication and work group relationships affecting productivity, satisfaction, and retention of its employees. This is especially important in institutions of higher education. In these institutions, there are many departments and divisions staffed with different groups communicating and working together on a daily basis. Generation Xers are leading Boomers, Boomers are leading Veterans, and Nexters are trying to teach the other generations the latest technology that will help do their job. It is important research continue to examine, using an empirical method, the relationship between generational differences and organization success.

The purpose of this paper is to review the literature on generational differences and its influence on leadership style and organizational success. The paper will discuss two current leadership styles---transformational and participative. The paper will define and review literature on the core values, leadership style, and work values of the different generational cohorts (Veterans, Boomers, Generation X, and Nexters). A quantitative study was conducted using interviews with leaders and individuals representing each of the generational cohorts to determine differences and there potential impact on organizational success. 


\section{LEADERSHIP STYLES}

The transformational leadership style focuses mainly on the ability of leaders to influence and inspire followers through their visions, creativity, goals, and actions. Bass and Avolio characterized the transformational leader behaviors as the "Four I's": Idealized influence, Inspirational motivation, Intellectual stimulation, and Individualized consideration.

Horsfall believed the participative leadership focuses more on the consensus aspect of the organization to meet their goals. The leader's desire to create a sense of ownership in the decision-making process underlines this model. There are positive and conflicting outcomes to the participative leadership style. Positively, participative leadership leads to quality decisions, consensus and acceptance, understanding of the decision by those responsible for implementing it, development of decision-making skills throughout the organization, enhanced motivation, job satisfaction, resolution of conflict, and team development. Conversely, participative leadership can lead to consensus at the same time as the need for authoritative leadership. There is also the need to consult along with the need to make timely and efficient decisions. Last, there is the need to reconcile external accountability pressures with the values and systems of the organization. It is important to take a closer look at what are the characteristics and behaviors of generations that may influence the development of their own leadership style. Is a leadership style more preferred by one generation compared to another? Has the failure to look at generational differences been a function of what Arsenault (2004) noted as, "the traditional, but erroneous, belief that people change their values, attitudes, and preferences as a function of age"?

\section{GENERATIONAL DIFFERENCES}

In recent years, research has focused on issues of diversity in the workplace, especially as it relates to generational differences. Researchers conclude that it is important to understand the impact that generational differences has on the organization to create an environment of harmony, mutual respect, and joint effort that may lead to organizational success. However, researchers Jurkiewicz, Arsenault, and Bartley, et al., concluded there is a lack of empirical research to validate the significance of these differences. Strauss \& Howe define generation has a cohort-group whose length approximates the span of life and boundaries and fixed by peer personality. There are slight differences in the years that span each cohort and the naming conventions of each. There is considerable agreement on what sets these generations apart from each other. Following is a review of the literature on how generations differ in their core values, work values, and leadership styles.

There are four major cohorts identified as representing the different generations. This paper uses the published work and definitions of Zemke to discuss each generational cohort. The Veterans were born 1922-1943. These individuals experience similar events and trends: The Great Depression, WWII, and the rise of labor unions. The Baby Boomers (1943-1960, other authors suggest 1946-1964) were defined by events, such as Vietnam, the Civil Rights movement, and assassinations. The Boomer era of 'free love' and abortions gave birth to the smallest cohort, Generation X.

Generation Xers was the generation (1960-1980) of the latchkey kids, single-parent homes, the Challenger disaster, and computers. The period 1980-2000 was the generation of the Nexters. Computers, schoolyard violence, Columbine, and Oklahoma City bombings characterize the Nexters generation.

\section{Core Values}

A set of core values identify each cohort that developed during the years representing their generation. For the Veterans, "their mind-set has so dominated our culture that every other set of beliefs is weighed against theirs". This mind-set, brought on by The Great Depression, consisted of core values of dedication and sacrifice. The values of delayed reward, duty before pleasure, honor, patience, and hard work characterized this generation.

Research believes the conservative nature of the Veterans, along with a grounded and logical attitude "causes many younger employees to view Veterans as harsh, gruff and rigid in their professional relationships and decisions in an organizational setting" (p. 29). Baby Boomers grew up in more optimistic and positive times, with the greatest economic expansion. They share core values of optimism, team orientation, work, and personal gratification. 
The core values of Veterans and Baby Boomers differ dramatically from Generation Xers. The Xers core values stem from a generation characterized by being "some of the first babies whose mothers took pills to prevent them. They came of age in an era of fallen heroes, a struggling economy, soaring divorce rates, and the phenomenon of the latchkey child..." This contributed to the development of core values described as diverse, global thinking, balance, technological, fun, informal, self-reliant, and pragmatic.

The Nexters are the newest generation. Their core values are similar to Generation X, but differ from the Veterans and the Baby Boomers. The Nexters generation brought back the rise of the child is the most important person, a belief that disappeared during the Generation X period. It is the 'soccer mom' mentality---it is all about the children--- that shaped their core values of optimism, civic duty, confidence, achievement, sociability, morality, street smarts, and diversity.

\section{Work Values}

There are major differences between the generations in the values they hold in the workplace. In 1983, Susan R. Rhodes conducted a review and a conceptual analysis of age-related differences in work attitudes and behavior. For the Veterans, their work values/ethics include such behaviors has loyalty and dependability.

The Veterans value obedience over individualism. This leads to a communication structure Zemke characterized as being "circuitous and indirect". They believe in authority and the power of those that are in charge to make the decisions that are best for the institution. For leaders, providing messages of motivation to Veterans that says they respect their experience, they are willing to listen to those experiences, and their perseverance is valued as well as rewarded.

Work environments that are characterized as democratic, humane, and casual influences the Baby Boomer work ethic. They began the revolution of participative management---consensus, team building, and quality circles. They are service oriented, driven, willing to 'go the extra mile', good at relationships, want to please, and good team players. The Boomer work ethic is very important as they occupy many of the middle- and upper-management positions in organizations today. However, they are uncomfortable with conflict, and/or judgmental to those who see things differently than they do. Some of the messages that motivate are similar to those of Veterans, consisting of expressing their value and contribution.

Generation Xers have a work ethic characterized by adaptability, independence, lack of intimidation by authority, and creativity. There is a downside to their independence on the job ---they are impatient, have poor people skills, inexperienced, and work from a place of cynicism. These perceptions lead to poor leadership with this group. They can be motivated to do good work by having flexible work hours, an informal work environment, and just the right amount of supervision. Providing messages to the effect of "do it your way" and "there aren't a lot of rules here" will motivate them.

Nexters work ethic embodies behaviors similar to those of the Veterans. They have beliefs in collective action, optimism about the future, and trust in centralized authority. They combine the teamwork of the Baby Boomers, the can-do attitude of the Veterans, and the technologically literacy of Generation X. Nexters believe hardworking and goal setting leads to the achievement of their dreams. The newness to the work place causes them to need more supervision and structure. They are very inexperienced in handling difficult issues with people. To motivate their work behavior, give messages of "you will be working with other bright and creative people," "You and your coworkers can help turn this company around." All these work ethics, core and work values inform and help to shape a person's leadership style.

\section{IMPACT OF GENERATIONAL DIFFERENCES ON LEADERSHIP STYLE}

Veterans' leadership style is very direct and command-and-control. The participative leadership style does not work. This group believes in the abilities of authority and do not see the value of teamwork and bringing in others in the decision-making process. Veterans do not think there should be equality among the members of a team. They like to take charge, delegate, and make the bulk of the decisions. 
This differs starkly from that of the Baby Boomers who advocate a leadership style characterized by their consensus work value and ethic. Boomers believe in the participative style of leadership; however, they have a difficult time implementing it in the workplace. This style of leadership requires skill in understanding, listening, communicating, motivating, and delegating. Baby Boomers lack these skills.

Because of the changing times in global competition, the need for a different leadership style has been the fuel that ignites the way the Generation Xer prefers to lead. Their leadership influenced by the Baby Boomers leadership --- espousing, but not practicing participative leadership --- is one of fairness, competence, and straightforwardness. Generation Xers lead by challenging the thinking and ideas of others, bringing in the masses to the decision-making process. However, they tend to lack people skills. Their straightforwardness may affect employee retention.

Nexters are new to the workplace, and few have had an opportunity to be in positions of leadership. The literature does not indicate their preferred leadership style. Core values, work values and ethics characterize the other generations' leadership style. It is an appropriate to assume their core and work values will characterize the Nexters generation. Thus, they will tend to lean toward a leadership style of transformational and participative. This study used structured interviews to highlight the differences in leadership style and leadership preference among the generations.

\section{METHOD}

\section{Participants}

This was a quantitative study with the purpose of determining whether generational differences influence organizational success. The research attempted to answer the following three research questions:

1. Are there differences between the four generations?

2. Are there differences in leadership style among the generations?

3. Do generational differences affect organizational success?

The researcher selected participants from a local community college in the Southwest region of Texas based on their generational cohort and leadership role in the organization. The Director of Student Life represented the Veteran generation. The President of the College represented the Baby Boomer. The Dean of Educational Support Services represented the Generation X cohort. A current student and college employee represented the Nexter generation.

\section{Instruments}

The study used two instruments adopted from the work by Paul Arsenault (2004). A questionnaire asked participants to respond to five questions to determine the generational cohort they identified. In addition, participants provided their actual age. Each participant responded to: 1) What three national and/or world events were especially important to you? 2) What are your favorite movies? 3) What are you favorite television shows? 4) What are your all-time favorite musical individuals or group? 5) Who are your favorite leaders?

The Checklist of Admired Leaders gathered participants' preferences for characteristics they admire in leaders. The instrument used a 1-10 scale (1 being the highest) to rank order the characteristics. The ten characteristics are based on the work of Kouzes and Posner. The ten characteristics are ambitious, caring, competent, determined, forward-looking, honest, imaginative, inspiring, loyal, and self-controlled. The research posed two additional questions to illicit responses related to the participant preferred leadership style and how to bridge the generational gap. 


\section{RESULTS}

Based on the five open-ended questions, all participants identified with the events and activities related to their generational cohort. The interview responses show similarities between the generations. Both the Veteran and Generation X discuss honesty as a core value. Both individuals talk about the importance of understanding the differences in the generations as a way to bridge the gap.

There were differences among the generations. The Boomer discussed taking care and commitment to self. Whereas, the Veteran states he admires individuals who knew how to surround themselves with individuals that could help them. The individual states they believe in taking care of themselves spiritually, physically, and mentally. This is consistent with the literature that states the Boomer generation focuses on personal gratification. The interview with the Nexter was consistent with responses from the Generation Xer in their core and work values of honesty, family, and balancing life and work.

When asked to complete the Checklist of Admired Leaders the Veteran, Boomer, and Nexter ranked competence as the top characteristic (Table 1). The ranking for honesty was ranked differently: Veteran (3), Boomer (5), Generation X (1), Nexter (4). A divergence occurred in the middle of the ranking. For example, the Baby Boomer ranked forward-looking two, but Veterans ranked it as 10 on the list. The Nexter and Generation Xer were in the middle with a ranking of five. The leadership styles of the three leaders differed. The Veteran seemed to prefer a style characterized by that generation cohort's core and work values. The Boomer leadership style as well seemed to mirror the generation's work and core values. It is in line with the participative leadership style, although the interviewee characterized it as servant leadership.

Table 1: Ranking of Admired Leaders by Interviewees

\begin{tabular}{lcccc}
\hline \multicolumn{1}{c}{ Characteristics } & Veteran & Baby Boomer & Generation X & Nexter \\
\hline Ambitious & 2 & 10 & 10 & 8 \\
Caring & 4 & 4 & 3 & 10 \\
Competent & 1 & 1 & 4 & 1 \\
Determined & 9 & 9 & 5 & 2 \\
Forward-looking & 10 & 2 & 5 & 5 \\
Honest & 3 & 5 & 1 & 4 \\
Imaginative & 6 & 6 & 7 & 9 \\
Inspiring & 8 & 3 & 9 & 6 \\
Loyal & 7 & 7 & 2 & 3 \\
Self-controlled & 5 & 8 & 6 & \\
\hline
\end{tabular}

\section{SUMMARY AND CONCLUSION}

The purpose of this research was to determine if there were differences among the generations. If there were differences, do these differences influence leadership style? Can generational differences affect an organization's success or failure? The research included interviews with four individuals representing each generation. The results are consistent with previous literature showing there are differences among the generations. Specifically, the characteristics individuals admired in leaders differed among the generations. In addition, they differed on the characterization of their leadership style. The Boomer discussed servant leadership. The Generation $\mathrm{X}$ labeled their leadership as situational. The Veteran lack of characterization using current leadership styles demonstrates the differences with the other two.

In recent years, there has been an expansion of the generation literature. However, extensive focus is on the group of individuals born 1960 to 1980---Generation X. Researchers provide strategies and recommendations on how to hire, retain, and manage this generation. However, it is important to continue focusing on all the generations. These generational differences can influence organizational success. Refocusing our attention on how the 
generations differ in the workplace will provide opportunities for organizations to become more successful: increased productivity, employee satisfaction, and employee retention. The lack of generational understanding and stereotyping allows for potential organizational strife and dissatisfaction that can lead to organizational failure: decreased productivity, employee dissatisfaction, and high employee turnover rates.

Researchers discuss two key strategies: aggressive communication and difference deployment. Aggressive communication refers to the use of over-communicating and placing a focus on the biases related to each generation. Difference deployment focuses on the deliberate creation of teams of individuals and situations that tap into the knowledge, skills, and talents of each generation. Difference deployment aligns with the participative and situational leadership styles. Thus, using this method would not be difficult for Baby Boomers, Generation Xers, and Nexters. As organizations move toward downsizing, fewer employees will be doing the majority of the work. Recognizing, understanding, and dealing with generational differences will become more important. Researcher should continue to examine empirically the effects of generational differences on organizational success or failure.

\section{AUTHOR INFORMATION}

Mecca M. Salahuddin is a doctoral student in The University of Incarnate Word's Department of Education. Her concentration of study is Organizational Leadership. She currently works at St. Philip's College as Director of the Institutional Planning, Research, and Effectiveness department. She has years of experience in higher education research. Previous work has included assisting aspiring undergraduate students with scholarly research and acceptance into graduate work. Her research interests include generational differences, organizational success, and other diversity issues affecting the workplace.

\section{REFERENCES}

1. Arsenault, P.M. (2004). Validating generational differences: A legitimate diversity and leadership issues. Leadership \& Organizational Development Journal, 25, 1/2, 124-141.

2. Bartley, S.J., Ladd, P.G., Morris, M.L. (2007). Managing the multigenerational workplace: answers for managers and trainers. CUPA-HR Journal, 28-34.

3. Leadership theories (n.d.), available at: http://www.changeminds.org/disciplines/leadership/theories/leadership theories.htm (accessed February 27, 2009).

4. Horsfall, C. (2001). Leadership Issues: Raising Achievement

5. Jurkiewicz, C.L. (2000). Generation $\mathrm{x}$ and the public employee. Public Personnel Management, 29, 1, 5574.

6. $\quad$ Kouzes, J.M. and Posner, B.Z. (2002). The Leadership Challenge, Jossey-Bass, San Francisco, CA.

7. Marsh, D.T. (1992). Leadership and its functions in further and higher education. Mendip Papers

8. Navahandi, A. (2009). The art and science of leadership, Upper Saddle River, New Jersey

9. Spaid, R.L., Parsons, M.H. (1999). Meeting the millennium's challenge: leading from where you are. New Directions for Community Colleges, 105, 13-19.

10. Tulgan, B. (1996). Correcting the 'slacker' myth - managing generation $\mathrm{x}$ in the workplace. Manage, 48, $1,14-16$.

11. Tulgan, B. (2004). Trends point to a dramatic generational shift in the future workforce. Employment Relations Today, 30, 4, 23-31.

12. Zemke, R., Raines, C., Filipczak, B. (1999). Generations gaps in the classroom. Training, 36, 11, 48-54.

13. Zemke, R., Raines, C., Filipczak, B. (2000). Managing the clash of veterans, boomers, xers, and nexters in your workplace $\left(2^{\text {nd }}\right.$ ed.), New York, NY: AMA Publications.

14. Zemke, R. (2001). Here come the millennials. Training, 38, 7, 44-49. 